\title{
Kritik terhadap Penggunaan IQ dalam Diagnosis Kesulitan Belajar Spesifik
}

\section{Critics on Utilizing IQ for Diagnosing Specific Learning Difficulties}

\author{
Satrio Budi Wibowo', Saifuddin Azwar ${ }^{2}$, MG Adiyanti ${ }^{3}$, Supra Wimbarti ${ }^{4}$ \\ ${ }^{1}$ Fakultas Keguruan dan Ilmu Pendidikan, Universitas Muhammadiyah Metro \\ 1,2,3,4 Fakultas Psikologi, Universitas Gadjah Mada
}

\section{Submit 11 Februari 2019 Diterima 16 Mei 2019 Terbit 22 Juni 2020}

\begin{abstract}
Specific learning disabilities (SLD) are closely defined as unexpected underachievement. Based on unexpected criteria for underachievement, discrepancy model is used in diagnosing SLD. According to the discrepancy model, SLD diagnosis can be established after finding a discrepancy between IQ and achievement. However, in recent years, researchers have questioned the validity of discrepancy model in diagnosing SLD. Some research concluded that the use of IQ in diagnosing SLD is not necessary. Thus, the SLD diagnostic criteria in some international guidelines are revised. One of the revised diagnostic manuals is Diagnostic and Statistical Manual of Mental Disorders (DSM). Criteria and diagnoses regarding SLD have changed, where the discrepancy model is no longer used. This paper seeks to explain various arguments that break the concept of discrepancy model, so that the use of intelligence tests is no longer needed in enforcing SLD diagnosis.
\end{abstract}

Keywords: diagnosis; discrepancy model; IQ; specific learning disabilities

Abstrak. Kesulitan belajar spesifik sering didefinisikan sebagai pencapaian rendah yang tidak terduga. Berdasarkan konsep mengenai pencapaian rendah yang tidak terduga, model kesenjangan digunakan dalam upaya mendiagnosis kesulitan belajar spesifik. Menurut model kesenjangan, diagnosis kesulitan belajar spesifik dapat ditegakkan setelah ditemukan adanya perbedaan antara IQ dan prestasi. Namun, dalam beberapa tahun terakhir, para peneliti mempertanyakan validitas model kesenjangan dalam mendiagnosis SLD. Beberapa penelitian menyimpulkan bahwa penggunaan IQ dalam mendiagnosis SLD tidak diperlukan. Jadi kriteria diagnostik SLD dalam beberapa pedoman internasional direvisi. Salah satu manual diagnostik yang direvisi adalah Manual Diagnostik dan Statistik Gangguan Mental (DSM). Kriteria dan diagnosis tentang kesulitan belajar spesifik telah berubah, di mana model kesenjangan tidak digunakan. Makalah ini berupaya menjelaskan berbagai argumen yang mematahkan konsep model kesenjangan, sehingga penggunaan tes kecerdasan tidak lagi diperlukan dalam menegakkan diagnosis kesulitan belajar spesifik.

Kata kunci: diagnosis; IQ; kesulitan belajar spesifik; model kesenjangan

\footnotetext{
${ }^{1}$ Korespondensi mengenai artikel ini dapat melalui: ${ }^{1}$ satrio-budi@mail.ugm.ac.id, ${ }^{2}$ sfazwar@ugm.ac.id,

3adiyanti_psy@ugm.ac.id, ${ }^{4}$ supra@ugm.ac.id
} 


\section{Pengantar}

Hingga saat ini, para ahli masih sulit untuk bersepakat mengenai definisi kesulitan belajar spesifik/spesific learning disabilities (SLD) (Kavale, 2005). Sebagai sebuah konstruk, SLD tidak dapat diobservasi, dan bersifat laten (Fletcher, 2012). Para ahli hanya dapat berhipotesis mengenai fitur utama dari konstruk SLD, terutama pada konsep mengenai pencapaian rendah yang tidak terduga (unexpected underachievement). Berdasarkan konsep pencapaian rendah yang tidak terduga, kemudian diusulkanlah atribut SLD, antara lain adalah prestasi rendah, kesenjangan performa kognitif potensial dan aktual, serta respons terhadap pembelajaran yang buruk (Fletcher, 2012). Tentunya berbagai hipotesis mengenai definisi SLD beserta atributnya perlu mendapatkan validasi ilmiah (Morris, 1988).

Konsep mengenai pencapaian rendah yang tidak terduga (unexpected underachievement), sebagai atribut SLD, mendorong banyak ahli untuk berusaha mencari cara mengukur pencapaian rendah yang tidak terduga, guna mengidentifikasi SLD (Fletcher, 2012). Muncullah konsep model kesenjangan (discrepancy model) sebagai upaya mengukur pencapaian rendah yang tidak terduga. Banyak ahli menggunakan model kesenjangan dalam mengidentifikasi anak yang mengalami SLD. Salah satu formula umum yang biasa digunakan dalam model kesenjangan untuk mendiagnosis SLD adalah dengan menghitung kesenjangan antara kemampuan aktual siswa dengan kemampuan potensial yang dimiliki (biasanya diwakili dengan skor IQ) (Siegel, 2003). Jika terjadi kesenjangan yang besar, maka siswa dapat didiagnosis SLD. Konsep model kesenjangan banyak digunakan praktisi psikologi dalam mengidentifikasi SLD.
Pada konsep model kesenjangan, pengukuran kecerdasan sangat penting untuk dilakukan. Pengukuran kecerdasan bertujuan untuk menentukan tingkat pencapaian yang bisa diharapkan dari individu. Sampai sebatas mana individu mampu mengembangkan potensi kecerdasannya. Penentuan tingkat capaian yang diharapkan merupakan bagian penting dalam konsep model kesenjangan dalam penentuan kriteria SLD (Ehri, Nunes, Stahl, \& Willows, 2018). Penggunaan tes kecerdasan dalam konsep model kesenjangan juga bertujuan menentukan metode pengajaran membaca untuk siswa disleksia (Ehri et al., 2018). Kedua alasan di atas, menjadi dasar penggunaan IQ dalam klasifikasi SLD.

Alasan lain mengapa IQ biasa digunakan untuk mendeteksi SLD adalah, untuk membedakan antara SLD dan retardasi mental (Siegel, 2003). Para ahli yang menggunakan tes IQ dalam mendeteksi SLD, bermaksud memisahkan penyebab rendahnya prestasi akademik siswa, antara yang disebabkan oleh SLD dan retardasi mental. Sehingga dengan menggunakan batasan IQ tertentu, para ahli dapat membedakan antara siswa yang SLD dengan retardasi mental. Penggunaan tes kecerdasan diharapkan meminimalisasi terjadinya diagnosis tumpang tindih antara SLD dan retardasi mental. Penggunaan tes kecerdasan pada konsep model kesenjangan, berasumsi bahwa IQ independen dalam mengukur kemampuan potensial, dan tidak terkait dengan kemampuan yang diukur dalam SLD (Siegel, 1989).

Banyak praktisi psikologi dan psikiatri di Indonesia yang menggunakan konsep model kesenjangan merujuk pada Diagnostic and Statistical Manual of Mental Disorders edisi ke 4 (DSM-4). Pada DSM-4 pengukuran IQ menjadi penting dilakukan 
dalam menentukan kriteria SLD. DSM-4 menjelaskan bahwa SLD didiagnosis jika prestasi akademik seseorang, seperti hasil tes terstandar mengenai membaca, tes matematika, atau ekspresi bahasa tulisan di bawah usia harapan, usia sekolah, dan level kecerdasan seharusnya (American Psychiatric Association, 1994). Beberapa variasi pendekatan statistik dapat digunakan untuk melihat apakah terdapat kesenjangan signifikan antara level akademik dan level kecerdasan (American Psychiatric Association, 1994). Misalnya, level bawah secara substansial dapat didefinisikan jika terdapat kesenjangan lebih dari 2 standar deviasi antara hasil capaian prestasi dan IQ. Berdasarkan kriteria tersebut, sangat jelas bahwa DSM4 mensyaratkan pengukuran IQ dalam menegakkan diagnosis SLD. Kriteria ini yang masih digunakan sebagian praktisi di Indonesia, dalam menegakkan diagnosis SLD.

Beberapa argumen di atas, menjadi dasar konsep model kesenjangan untuk menggunakan IQ dalam diagnosis SLD. Beberapa argumen di atas jika disimpulkan mencakup tiga bahasan pokok, pertama terkait ketepatan konsep pencapaian rendah yang tidak terduga dalam mendefinisikan SLD, kedua terkait mengetahui tingkat capaian potensial individu dengan IQ, serta membedakan antara SLD dengan retardasi mental, dan ketiga terkait diagnosis SLD bersandar pada DSM-4. Konsep model kesenjangan sendiri sebenarnya telah mendapat kritik banyak ahli (Vaughn \& Fuchs, 2003). Sehingga penggunaan konsep model kesenjangan dalam diagnosis SLD perlu dipertanyakan keakuratannya (Siegel, 2003). Tulisan ini berusaha menjelaskan ketidaktepatan penggunaan IQ dan konsep model kesenjangan dalam mendiagnosis SLD.

\section{Pembahasan}

\section{Sejarah Definisi SLD}

Diagnosis terhadap SLD sangat terkait dengan bagaimana SLD didefinisikan. Sedangkan konsep definisi SLD mengalami perubahan dari waktu ke waktu, seiring ditemukannya hasil-hasil penelitian terbaru. Awal penelitian tentang SLD dimulai pada awal tahun 1800-an, Gall dan Bouillaud meneliti tentang hubungan antara otak-perilaku, serta tulisan Broca dan Wernicke mengenai gangguan bahasa dan afasia (Hallahan \& Mercer, 2002). Penelitian Gall dan Bouillaud serta tulisan Broca dan Wernicke merupakan awal ketertarikan para ahli terhadap topik gangguan dalam SLD yang terkait dengan otak manusia. Kemudian, Kussmaul pada tahun 1877 mengenalkan pertama kali penamaan buta huruf (word blindness), untuk sebutan bagi kebutaan seseorang terhadap teks yang khas, meskipun memiliki kemampuan visual, ucapan, dan kognitif yang baik (Hallahan \& Mercer, 2002). Pada tahun 1887, Wagner menyempurnakan definisi ini dan menciptakan istilah "disleksia" (Wagner, 1973).

Melihat sejarah perkembangan definisi SLD, terlihat bahwa perkembangan definisi SLD sangat terkait dengan perkembangan definisi mengenai disleksia. Bahkan, saat ini, disleksia menjadi bidang yang paling umum dan banyak diteliti dalam SLD (Shaywitz, Colker, Shaywitz, \& Simon, 2012). Penelitian mengenai definisi dan penyebab disleksia, menjadi pijakan dalam memahami definisi SLD secara luas. Oleh sebab itu, proses identifikasi SLD sangat berkaitan erat dengan perkembangan proses identifikasi pada disleksia.

Konsep identifikasi disleksia mulai menemui pijakan pada tahun 1932. Pada tahun 1932 Monroe mulai memperkenalkan konsep model kesenjangan sebagai 
cara untuk mengidentifikasi disabilitas membaca (Monroe, 1932). Mulai saat itu, konsep model kesenjangan mulai mendapatkan perhatian dari para ahli. Terpengaruh konsep model kesenjangan, pada tahun 1962, Kirk mulai mengenalkan istilah "kesulitan belajar" (Kirk, 1962). Definisi mengenai "kesulitan belajar" yang dikenalkan Kirk, sangat dipengaruhi oleh konsep model kesenjangan. Kirk menjelaskan bahwa ketidakmampuan belajar mengacu pada keterbelakangan, gangguan, atau perkembangan yang tertunda pada satu atau lebih proses berikut ini; bicara, bahasa, membaca, menulis, aritmetika, atau subjek sekolah lainnya. Hal tersebut dihasilkan dari kecacatan psikologis yang kemungkinan disebabkan oleh disfungsi serebral, gangguan emosi atau perilaku. Kemudian Kirk menekankan kembali, bahwa "kesulitan belajar" bukan hasil retardasi mental, kegagalan sensorik, atau faktor budaya (Kirk, 1962). Pada definisi kirk mulai ditegaskan bahwa penyebab kesulitan belajar bukan berasal dari kemampuan potensial. Kemampuan potensial misalnya adalah retardasi mental, yang biasa diketahui setelah diukur menggunakan tes kecerdasan. Sehingga jika disimpulkan, kesulitan belajar menurut definisi Kirk adalah murni gangguan pada proses bicara, bahasa, membaca, menulis, aritmetika, atau subjek sekolah lain, dan tidak terkait sama sekali dengan kemampuan potensial kecerdasan siswa.

Selanjutnya, pada tahun 1965, Bateman seorang mahasiswa Kirk, mendefinisikan kesulitan belajar dengan memasukkan gagasan Monroe mengenai konsep model kesenjangan (Zumeta, Zirkel, \& Danielson, 2014). Bateman menyebutkan bahwa anak-anak yang memiliki kesulitan belajar adalah mereka yang menunjukkan perbedaan yang signifikan antara kemampuan potensial dengan tingkat kinerja aktual (Bateman, 1965). Gangguan pada tingkat kinerja aktual adalah gangguan yang terkait dengan gangguan dasar dalam proses pembelajaran, yang mungkin disertai dengan disfungsi sistem saraf pusat, tetapi bukan gangguan akibat keterbelakangan mental, proses pendidikan yang salah, budaya, gangguan emosional yang parah, atau kehilangan kemampuan sensorik.

Bateman memasukkan gagasan Kirk mengenai konsep SLD. Bateman mengecualikan gangguan yang bersifat kemampuan potensial dalam mendefinisikan SLD. Artinya, SLD merupakan murni gangguan yang dicirikan oleh rendahnya kemampuan aktual. Definisi Bateman, memperkenalkan konsep, bahwa SLD dapat dicirikan dengan adanya perbedaan signifikan antara bakat dan pencapaian aktual. Konsep SLD yang dikemukakan Bateman kemudian menjadi persyaratan kelayakan utama untuk klasifikasi SLD. Kemudian, Individuals with Disabilities in Education Act (IDEA) mulai menggunakan konsep klasifikasi SLD yang dikemukakan Bateman sebagai dasar kebijakan pendidikan inklusi (Zumeta et al., 2014). Pada tahun 1977, Kantor Program Pendidikan Khusus (Office of Special Education Programs [OSEP]) Amerika Serikat mengkodifikasi kerangka perbedaan kognitif sebagai satusatunya metode untuk identifikasi SLD, yang mewajibkan identifikasi perbedaan antara kemampuan potensial (biasanya diukur melalui tes IQ) dengan capaian prestasi akademik (Zumeta et al., 2014).

Konsep SLD yang menjelaskan bahwa pencapaian rendah yang tidak terduga (unexpected underachievement), dapat diukur dengan mengecualikan gangguan yang bersifat kemampuan potensial, mulai diadopsi oleh berbagai buku panduan diagnosis SLD. Salah satunya DSM-4, kriteria kesenjangan dijadikan dasar 
dalam mendefinisikan SLD. Sebagaimana disebutkan sebelumnya, konsep model kesenjangan mengharuskan terdapatnya kesenjangan antara capaian prestasi dengan IQ sebagai syarat dalam menegakkan diagnosis SLD. Kriteria diagnosis SLD dalam DSM-4, yang merupakan panduan internasional, banyak dijadikan rujukan para ahli dan praktisi psikologi di Indonesia dalam menegakkan diagnosis SLD.

Namun, banyak kritik terhadap konsep model kesenjangan. Siegel (1989) mengkritik inkonsistensi dalam menentukan diagnosis SLD dengan menggunakan model kesenjangan IQ - prestasi. Beberapa penelitian menunjukkan bahwa anak-anak yang memiliki SLD, tidak harus selalu menunjukkan kesenjangan antara hasil IQ dengan prestasi akademik. Sehingga konsep kecerdasan tidak diperlukan untuk mendefinisikan SLD (Siegel, 1989). Stanovich, (2008) mengkritik bahwa konsep model kesenjangan tidak memiliki pijakan ilmiah yang baik, dan memiliki sifat layaknya ilmu pengetahuan semu (pseudoscience). Dua penelitian metaanalisis yang dilakukan oleh Hoskyn \& Swanson (2000) dan Stuebing et al., (2002) menunjukkan bahwa konsep model kesenjangan tidak memiliki pijakan validitas yang kuat. Hal ini menunjukkan, bahwa konsep model kesenjangan tidak banyak memiliki bukti pendukung penelitian yang kuat. Kritik lain terhadap penggunaan konsep model kesenjangan untuk mengidentifikasi SLD, adalah bahwa penerapan model kesenjangan dapat menyebabkan tertundanya penyediaan layanan pendidikan khusus. Para pengkritik berpendapat bahwa menunggu siswa untuk cukup dewasa dan menunjukkan kesenjangan antara kemampuan potensial dengan prestasi akademik merupakan model "menunggu-untuk-gagal" (wait-tofail) (Fuchs \& Deshler, 2007). Artinya, siswa harus mengalami kegagalan dalam belajar terlebih dahulu sehingga terjadi kesenjangan yang cukup antara IQ dan prestasi belajar, untuk menjamin pemberian layanan pendidikan khusus.

Berbagai kritik dari para ahli mendapatkan respons dari departemen pendidikan di Amerika Serikat. Pada tahun 2004 otorisasi ulang terhadap IDEA menyebabkan beberapa perubahan utama dalam prosedur identifikasi SLD (Fletcher, 2012). Identifikasi SLD dalam IDEA mulai mengenalkan pendekatan respons terhadap intervensi/Response to Intervention (RtI) (Fletcher, 2012). Sehingga siswa yang memiliki prestasi akademik rendah langsung mendapatkan intervensi, kemudian perkembangan siswa terhadap intervensi dicatat, ketika siswa tidak menunjukkan perkembangan signifikan terhadap intervensi yang diberikan dapat dimasukkan ke dalam anak berisiko SLD. Pencatatan respons siswa terhadap intervensi membutuhkan evaluasi yang komprehensif dan menggunakan berbagai sumber informasi (Fletcher, 2012).

Perubahan pada IDEA berdampak pada revisi terhadap DSM, yang merupakan pedoman internasional bagi praktisi psikiatri dan psikologi. Terdapat banyak perubahan terkait kriteria SLD dalam DSM-5 yang dipublikasikan oleh American Psychiatric Association (APA) pada bulan Mei 2013. Beberapa kriteria diagnosis SLD pada DSM-4 telah direvisi pada DSM-5, pengukuran IQ yang menjadi syarat konsep model kesenjangan dihilangkan. Konsep model kesenjangan yang terdapat pada DSM-4, digantikan dengan beberapa kriteria diagnosis, yang salah satunya memasukkan pendekatan respons terhadap intervensi/Response to Intervention (RtI) (Tannock, 2014). 


\section{Perubahan Kriteria SLD dalam DSM}

DSM telah menjadi panduan internasional para praktisi psikologi dan psikiatri dalam menegakkan diagnosis. Sebagaimana disebutkan sebelumnya kriteria diagnosis SLD pada DSM-4, telah mengalami perubahan pada DSM-5. Penggunaan IQ telah menjadi inti dari penilaian psikologis dalam diagnosis SLD selama beberapa dekade, menjadi tidak diperlukan lagi dalam DSM-5, kecuali ketika terdapat kecurigaan terhadap adanya kesulitan kecerdasan/retardasi mental pada anak (Tannock, 2014). Tannock yang merupakan salah satu panelis ahli dalam revisi DSM-5 untuk tema SLD, menjelaskan bahwa persyaratan perbedaan antara capaian IQ dengan prestasi akademik, telah diubah dan digantikan dengan 4 kriteria (A-D) yang harus dipenuhi dalam menegakkan diagnosis SLD.

Penjelasan Tannock (2014) terhadap keempat kriteria (A-D) tersebut adalah ; Kriteria A, terdapat kemunculan karakteristik utama SLD (setidaknya satu dari enam gejala kesulitan belajar yang telah bertahan selama setidaknya 6 bulan meskipun ada bantuan tambahan atau instruksi yang ditargetkan). Kriteria B, mengacu pada pengukuran terhadap karakteristik utama SLD (pada anak usia 5 tahun keterampilan akademik secara substansial dan kuantitatif terpengaruh dan di bawah nilai yang diharapkan, menyebabkan terjadinya penurunan dalam kegiatan akademik, kinerja, atau perilaku sehari-hari, sebagaimana ditunjukkan oleh hasil pengukuran prestasi akademik individual terstandar dan penilaian klinis yang komprehensif). Kriteria C mengacu pada usia awal munculnya masalah (selama tahun-tahun usia sekolah, meskipun pada beberapa individu mungkin tidak sepenuhnya muncul sampai usia dewasa muda), dan Kriteria D menentu- kan gangguan mana yang harus disingkirkan sebelum diagnosis SLD ditegakkan (disabilitas intelektual/ retardasi mental, masalah pada pendengaran dan visual, gangguan mental dan gangguan neurologis lainnya) atau kondisi lingkungan yang buruk (kesulitan psikososial, kurang mahir dengan bahasa setempat, pembelajaran yang tidak memadai).

Berdasarkan perubahan yang terjadi, maka dapat disimpulkan bahwa psikolog mungkin dapat beralih dari model 'penilaian untuk diagnosis' kepada model 'penilaian untuk intervensi' dalam mendiagnosis disleksia (Tannock, 2014). Sehingga ketika hasil penilaian akademik siswa mengalami kemunduran dibanding anak lain, maka rencana intervensi dapat segera dilakukan (Tannock, 2014). Penghapusan kriteria kesenjangan prestasi-IQ memberikan kesempatan untuk anak-anak dengan SLD dan IQ lebih rendah (tetapi yang tidak memiliki disabilitas intelektual/ retardasi mental) untuk mendapatkan layanan pendidikan khusus. Berdasarkan beberapa penelitian anak-anak SLD dengan IQ rendah menunjukkan respons yang sama terhadap intervensi seperti halnya anak-anak SLD dengan IQ yang lebih tinggi (Tannock, 2014).

Alasan pengukuran IQ tidak diperlukan dalam diagnosis $S L D$

Penolakan utama terhadap konsep model kesenjangan antara IQ-prestasi belajar adalah digunakannya tes kecerdasan dalam diagnosis SLD (Vaughn \& Fuchs, 2003). Hal ini didukung dengan hasil-hasil penelitian yang memberikan kesimpulan bahwa pengukuran IQ dalam diagnosis SLD tidak diperlukan (Siegel, 1989). Pengukuran IQ tidak diperlukan karena banyak anak yang memiliki SLD tidak menunjukkan adanya kesenjangan antara IQ-prestasi belajar, bahkan pada anak 
yang memiliki capaian prestasi belajar normal justru menunjukkan kesenjangan antara IQ-prestasi belajar (D'Angiulli \& Siegel, 2003). Secara umum, alasan utama penolakan terhadap penggunaan IQ disebabkan terdapatnya inkonsistensi diagnosis SLD dengan melibatkan IQ.

Penelitian menunjukkan bahwa pada anak dengan prestasi membaca yang rendah, yang memiliki kecerdasan ratarata (misal IQ $\geq 80$ ) antara yang terdapat kesenjangan prestasi-IQ dengan yang tidak terdapat kesenjangan prestasi-IQ, tidak terdapat bukti kondisi klinis yang berbeda. Misalnya, studi yang menguji efek perbedaan kriteria diagnostik pada anggota keluarga yang secara hereditas memiliki SLD dalam hal pengejaan, tidak ditemukan bukti bahwa penggunaan kriteria diagnostik yang berbeda (kriteria perbedaan prestasi-IQ vs kriteria prestasi rendah), akan membuat berbeda dalam mendiagnosis anak yang secara hereditas memiliki anggota keluarga yang SLD (Schulte-Körne, Deimel, Müller, Gutenbrunner, \& Remschmidt, 1996). Artinya penggunaan kriteria diagnosis hanya dengan menggunakan kriteria prestasi rendah saja, pada siswa SLD yang memiliki IQ $\geq 80$, terbukti ditemukan jejak hereditas/turunan SLD dalam hal pengejaan. Sehingga, penggunaan IQ untuk memastikan terdapat kesenjangan prestasi-IQ, baru kemudian anak dapat didiagnosis SLD, tidak diperlukan. Jika IQ digunakan untuk memastikan terdapat kesenjangan prestasi-IQ, baru kemudian ditegakkan diagnosis SLD, maka anakanak yang menunjukkan prestasi membaca yang rendah tapi tidak menunjukkan kesenjangan prestasi-IQ, luput dari diagnosis SLD.

Banyak penelitian lain yang membuktikan ketidaktepatan konsep model kesenjangan dalam mendiagnosis SLD.
Penelitian Maehler \& Schuchardt (2009) berusaha membandingkan antara tiga kelompok. Kelompok pertama, 27 anak dengan ketidakmampuan belajar membaca dan IQ normal. Kelompok kedua, 27 anak dengan ketidakmampuan belajar membaca dan IQ rendah. Kelompok ketiga, yang merupakan kelompok kontrol, terdiri dari 27 anak-anak dengan tingkat prestasi sekolah normal dan IQ normal. Ketiga kelompok penelitian tersebut diberikan tugas ingatan kerja (working memory) yang terkait dengan kemampuan membaca yaitu, loop fonologis (phonological loop), sketsa visual-spasial (visual-spatial sketchpad) dan keterampilan eksekutif pusat (central executive skills). Hasil penelitian menunjukkan bahwa tidak terdapat perbedaan kemampuan dalam tugas ingatan kerja (working memory) yang signifikan, antara kelompok anak yang memiliki kemampuan belajar membaca rendah dan IQ normal, dengan kelompok anak yang memiliki prestasi membaca rendah dan IQ rendah. Hasil penelitian ini mengindikasikan tidak diperlukannya pengukuran IQ untuk dapat membedakan kemampuan kognitif terkait tugas membaca pada anak dengan prestasi belajar membaca yang rendah. Maehler dan Schuchardt (2009) menyimpulkan bahwa tidak terdapat perbedaan fungsi kognitif (terkait membaca) yang disebabkan perbedaan tingkat kecerdasan pada anak yang memiliki prestasi belajar membaca yang rendah.

Penelitian Fletcher, Denton, dan Francis (2005) membandingkan empat macam model diagnosis SLD (a) model kesenjangan, (b) prestasi rendah, (c) perbedaan individu, dan (d) respons terhadap instruksi. Hasil penelitian menunjukkan bahwa diagnosis model kesenjangan menunjukkan bukti validitas diskriminan yang rendah. Tes kecerdasan 
yang digunakan untuk melihat kesenjangan kemampuan potensialprestasi, terbukti kurang memiliki bukti validitas untuk identifikasi SLD.

Penelitian Francis et al. (2005) menunjukkan bahwa titik-potong (cutpoints) dalam konsep model kesenjangan, yang digunakan untuk klasifikasi SLD, tidak stabil dari waktu ke waktu. Hasil penelitian longitudinal di Connecticut Amerika Serikat, menunjukkan bahwa $39 \%$ siswa pada kelas 3 (grade 3) didiagnosis masuk pada kriteria SLD dan non SLD, pada kelas 5 (grade 5) mengalami perpindahan kelompok kriteria (SLD menjadi non SLD, non SLD menjadi SLD). Temuan Francis et al., (2005) menunjukkan bahwa penggunaan IQ dalam konsep model kesenjangan, yang digunakan untuk menentukan titik-potong (cutpoints) dalam diagnosis SLD tidak memiliki bukti konsistensi hasil yang baik.

Penelitian Siegel (1992) berusaha membandingkan kinerja berbagai tugas membaca, mengeja, pemrosesan fonologis, bahasa, dan ingatan, pada anak-anak dengan disleksia yang tingkat bacaannya secara signifikan lebih rendah daripada yang diperkirakan oleh skor IQ dengan anak-anak yang memiliki kemampuan baca buruk, namun memiliki skor membaca konsisten dengan nilai IQ mereka (kemampuan baca dan IQ sama-sama rendah). Hasilnya, meskipun anak-anak dengan disleksia memiliki skor IQ yang secara signifikan lebih tinggi daripada anak dengan kemampuan baca rendah, kedua kelompok ini tidak berbeda dalam kinerja membaca, mengeja, pemrosesan fonologis, dan pada sebagian besar tugas bahasa dan ingatan. Hasil penelitian Siegel (1992), menegaskan bahwa tidak diperlukannya IQ (konsep model kesenjangan) untuk membedakan antara individu dengan disleksia dan pembaca yang buruk. Karena kedua kelompok penelitian tersebut sama-sama menunjukkan keterbatasan membaca, dan memiliki kekurangan dalam pemrosesan fonologis, ingatan verbal, dan kesadaran sintaksis. Penggunaan tes kecerdasan dalam konsep model kesenjangan untuk mendiagnosis SLD hanya memberikan kerugian, di mana anak-anak yang memiliki kemampuan membaca rendah namun tidak masuk dalam kriteria diagnosis SLD, tidak mendapatkan intervensi yang sama dengan anak-anak yang telah didiagnosis SLD.

Beberapa penelitian meta-analisis juga telah dilakukan untuk menguatkan bukti, tidak perlunya penggunaan IQ dalam diagnosis SLD. Hoskyn dan Swanson (2000) melakukan penelitian meta-analisis terhadap 19 penelitian. Hasil penelitian Hoskyn dan Swanson (2000) menunjukkan bahwa anak-anak dengan ketidakmampuan membaca (yang didiagnosis dengan model kesenjangan) mengungguli siswa berprestasi membaca rendah (prestasi-IQ sama-sama rendah) pada ukuran pengetahuan leksikal, pengetahuan sintaksis, dan pemrosesan visual-spasial. Pengujian model lebih lanjut mendukung hipotesis terhadap ukuran kognitif lainnya, anak-anak dengan disabilitas membaca (didiagnosis dengan model kesenjangan) menunjukkan defisit fonologis yang sama dengan siswa berprestasi membaca rendah (prestasi-IQ sama-sama rendah). Stuebing et al. (2002) melakukan penelitian meta-analisis terhadap 46 penelitian yang membahas validitas klasifikasi SLD dengan menggunakan konsep model kesenjangan prestasiIQ. Hasil penelitian menunjukkan bahwa hanya terdapat sedikit bukti validitas penggunaan konsep model kesenjangan prestasi-IQ dalam mendiagnosis SLD, 
sehingga kegunaan IQ dalam diagnosis SLD, diragukan.

Berdasarkan penjabaran hasil-hasil penelitian individual dan meta-analisis yang menguji penggunaan tes IQ dalam konsep kesenjangan, memberikan bukti bahwa penggunaan IQ dalam diagnosis SLD tidak terlalu diperlukan. Sehingga penggunaan tes kecerdasan justru dapat memberikan kerugian pada anak-anak yang memiliki kesulitan belajar membaca namun nilai IQ rendah, sehingga berdasarkan konsep model kesenjangan tidak dapat didiagnosis sebagai SLD. Anak yang memiliki kesulitan belajar membaca namun tidak terdiagnosis sebagai SLD, tidak akan mendapatkan intervensi yang tepat bagi kesulitan belajar membaca yang mereka alami.

Argumen lain digunakannya IQ dalam diagnosis SLD adalah, IQ ditujukan untuk memenuhi kriteria pengecualian (exclusion), dimana SLD harus dibedakan dengan disabilitas intelektual/retardasi mental. Penggunaan IQ untuk membatasi kriteria SLD dengan retardasi mental, sebenarnya tidak perlu dilakukan. Pertama, masih belum terdapat kesepakatan universal mengenai batasan IQ yang memisahkan antara SLD dan retardasi mental (Siegel, 2003). Sehingga sulit untuk dipastikan, pada batasan IQ berapa seseorang dipastikan mengalami SLD namun tidak mengalami retardasi mental. Karena beberapa penelitian menunjukkan bahwa kasus disleksia juga ditemukan pada individu yang memiliki IQ rendah (Siegel, 1992; Maehler \& Schuchardt, 2009). Kedua, Siegel (2003) berargumen jika seseorang dapat melakukan percakapan bermakna, dapat menentukan jalannya untuk dapat menuju ruang tes, dan dapat memahami instruksi serta menjawab pertanyaan, hal tersebut dapat dijadikan alasan rasional bahwa individu memiliki cukup kemampuan untuk belajar keterampilan membaca dan berhitung. Sehingga ketika individu mengalami kegagalan dalam belajar dan membaca, bisa diasumsikan bukan disebabkan oleh disabilitas intelektual atau retardasi mental.

Asumsi lain yang menyebutkan bahwa IQ independen dalam mengukur kemampuan potensial, dan tidak terkait dengan kriteria SLD dibantah oleh beberapa ahli. Beberapa aspek dalam IQ sangat mungkin terkait dengan aspek SLD, misalnya pada kasus disleksia. Beberapa aspek yang diukur dalam IQ seperti pengetahuan khusus, kosa kata, bahasa ekspresif, dan keterampilan ingatan juga merupakan bagian aspek dari kriteria disleksia (Siegel, 1989). Sehingga anak-anak dengan SLD sangat mungkin mengalami masalah pada beberapa aspek yang terdapat dalam IQ (Siegel \& Ryan, 2018; Bradley \& Vellutino, 2006). Dapat diasumsikan bahwa anak yang memiliki SLD dan bermasalah dalam salah satu atau semua aspek tersebut, mungkin berakhir dengan skor IQ yang lebih rendah daripada anak yang tidak memiliki masalah pada aspek tersebut (Siegel, 1989). Studi seperti yang dilakukan oleh (Rourke \& Finlayson, 1978) dan Siegel \& Feldman (1983) telah menunjukkan bahwa ada beberapa jenis SLD, khususnya, yang memiliki masalah aritmetika, yang mungkin memiliki gangguan keterampilan motorik halus dan kemampuan visualspasial, dalam kasus anak-anak ini, kinerja IQ tidak akan menjadi ukuran akurat "kecerdasan" mereka. Jika disimpulkan, skor IQ yang rendah mungkin merupakan konsekuensi dari SLD, dan skor IQ yang didapat menggambarkan lebih rendah (underestimate) kecerdasan sebenarnya dari individu dengan SLD (Siegel, 1989). Argumen tersebut menjelaskan bahwa konsep 
mengenai IQ mungkin tidak independen dengan konsep mengenai SLD.

Argumen lain digunakannya IQ dalam diagnosis SLD ditujukan untuk menentukan metode pengajaran membaca, mengingat beberapa metode pengajaran membaca tidak efektif untuk siswa dengan IQ rendah (Ehri et al., 2018). Studi metaanalisis yang telah dijabarkan sebelumnya, justru membuktikan bahwa argumen IQ dapat digunakan untuk menentukan metode pengajaran membaca yang lebih efektif, tidak memiliki bukti validitas yang kuat (Hoskyn \& Swanson, 2000; Stuebing et al., 2002). Penelitian (Shaywitz, Morris, \& Shaywitz, 2008) menemukan bahwa perkembangan keterampilan membaca jangka panjang antara siswa kesulitan belajar membaca dengan IQ rendah dan IQ normal, tidak memiliki perbedaan. Menggunakan IQ atau dengan kesenjangan IQ-prestasi, merupakan prediktor yang lemah dalam menentukan model intervensi (Stuebing, Barth, Molfese, Weiss, \& Fletcher, 2009; (Vellutino, Scanlon, \& Lyon, 2000). Bahkan, Tanaka et al. (2015) dalam studi pencitraan otak fungsional (functional magnetic resonance imaging) tidak menemukan adanya perbedaan dalam pola aktivasi otak dari dua sampel anak yang diidentifikasi dengan model kesenjangan IQ-prestasi dan anak yang diidentifikasi memiliki pencapaian kemampuan membaca rendah, ketika membaca kata-kata bermakna dan katakata tak bermakna (pseudoword). Buktibukti penelitian tersebut menjelaskan bahwa penggunaan IQ untuk menentukan metode pengajaran membaca bagi siswa disleksia atau non disleksia, tidak diperlukan.

\section{Penutup}

Berdasarkan uraian di atas dapat disimpulkan, bahwa penggunaan IQ untuk diagnosis SLD telah direvisi pada beberapa panduan dan pedoman diagnosis. Panduan internasional yang digunakan para praktisi psikiatri dan psikologi semisal DSM juga telah melakukan revisi, sehingga pengukuran IQ tidak menjadi syarat dalam diagnosis SLD. Tannock (2014) menjelaskan, bahwa perubahan paradigma ini merujuk pada konsep model respons to Intervention (RtI). Konsep model RtI menawarkan efisiensi intervensi terhadap SLD, sehingga intervensi dapat lebih cepat diberikan dibandingkan konsep model kesenjangan. Konsep RtI menawarkan intervensi terstandar berbasis penelitian yang langsung dapat diterapkan pada anak yang menunjukkan indikasi mengalami SLD. Proses asesmen dalam RtI juga lebih murah, karena tidak mengeluarkan biaya tambahan untuk administrasi tes kecerdasan. Cukup menggunakan tes prestasi tertentu yang dapat mengukur fungsi aktual anak terkait kesulitan belajar yang dialami (Siegel, 1989).

Terdapat alternatif model klasifikasi dalam diagnosis SLD selain penggunaan model kesenjangan dan model RtI, yaitu model pengukuran neurologis. Pengukuran neuropsikologis juga dapat dilakukan dengan alat ukur psikometri yang mengukur fungsi kognitif. Walaupun, alat ukur psikometri yang mengukur fungsi kognitif lebih tepat digunakan sebagai informasi untuk rencana intervensi bagi anak, bukan untuk keperluan diagnosis (Tannock, 2014). Walaupun tidak digunakan untuk keperluan diagnosis, tes kognitif yang disusun untuk mendeteksi SLD dapat digunakan untuk mendukung konsep model Respons to Intervention (RtI). 
Proses asesmen dalam RtI menawarkan keleluasan bagi sekolah-sekolah di Indonesia untuk dapat melakukan assessment bagi siswa yang memiliki kesulitan belajar spesifik. Banyak sekolah-sekolah di Indonesia yang tidak memiliki tenaga psikolog untuk melakukan administrasi tes kecerdasan. Beberapa alat tes deteksi dini mengenai kesulitan belajar spesifik telah dikembangkan di Indonesia, di antara nya adalah, tes deteksi dini disleksia yang dikembangkan oleh penulis sendiri. Tes deteksi dini kesulitan belajar spesifik, biasanya tidak membutuhkan kualifikasi pendidikan profesi psikologi. Sehingga dapat digunakan pada tiap sekolah di Indonesia yang tidak memiliki tenaga psikolog sekolah.

\section{Daftar Pustaka}

American Psychiatric Association. (1994). DSM-IV diagnostic and statistical manual of mental disorder. In American Psychiatric Organization, 33.

Bateman, B. (1965). An educational view of a diagnostic approach to learning disorders. Learning Disorders, 1, 219220.

Bradley, L., \& Vellutino, F. R. (2006). Dyslexia: Theory and research. British Journal of Educational Studies, 29(1), 95. doi: $\underline{10.2307 / 3120437}$

D'Angiulli, A., \& Siegel, L. S. (2003). Cognitive functioning as measured by the WISC-R: Do children with learning disabilities have distinctive patterns of performance? Journal of Learning Disabilities, 36(1), 48-58. doi: $\underline{10.1177 / 00222194030360010601}$

Ehri, L. C., Nunes, S. R., Stahl, S. A., \& Willows, D. M. (2018). Systematic phonics instruction helps students learn to read: Evidence from the national reading panel's meta- analysis. American Educational Research Association Stable Systematic Phonics Instructi. 71(3), 393-447.

Fletcher, J. M. (2012). Classification and identification of learning disabilities. In Learning about learning disabilities (Fourth Ed). doi: 10.1016/b978-0-12388409-1.00001-1

Fletcher, J. M., Denton, C., \& Francis, D. J. (2005). For the identification of learning disabilities. Journal of Learning Disabilities, 38(6), 545-552. doi: $\underline{10.1177 / 00222194050380061101}$

Francis, D. J., Fletcher, J. M., Stuebing, K. K., Lyon, G. R., Shaywitz, B. A., \& Shaywitz, S. E. (2005). Psychometric approaches to the identification of LD. Journal of Learning Disabilities, 38(2), 98-108. doi: $\underline{10.1177 / 00222194050}$ $\underline{380020101}$

Fuchs, D., \& Deshler, D. D. (2007). What we need to know about responsiveness to intervention (and Shouldn't be afraid to ask). Learning Disabilities Research \& Practice, 22(2), 129-136. doi: 10.1111/j.1540-5826. 2007.00237.x

Hallahan, D. P., \& Mercer, C. D. (2002). Learning disabilities: Historical perspectives. In R. Bradley, L. Danielson, \& D. P. Hallahan (Eds.). Identification of learning disabilities: Research to practice, 1-67. Mahwah, NJ: Erlbaum.

Hoskyn, M., \& Swanson, H. L. (2000). Cognitive processing of low achievers and children with reading disabilities: A selective meta-analytic review of the published literature. School Psychology Review, 29, 102-119.

Kavale, K. A. (2005). Identifying specific learning disability: Is responsiveness to intervention the answer? Journal of Learning Disabilities, 38(6), 553-562. doi: $\underline{10.1177 / 00222194050380061201}$ 
Kirk, S. A. (1962). Educating exceptional children. Boston: Houghton Mifflin.

Maehler, C., \& Schuchardt, K. (2009). Working memory functioning in children with learning disabilities: Does intelligence make a difference? Journal of Intellectual Disability Research, 53(1), 3-10. doi: 10.1111/j.13652788.2008.01105.x

Monroe, M. (1932). Children who cannot read. Chicago: The University of Chicago Press.

Morris, R. D. (1988). Classification of learning disabilities: Old problems and new approaches. Journal of Consulting and Clinical Psychology, 56(6), 789-794. doi: $\underline{10.1037 / 0022-006 X .56 .6 .789}$

Rourke, B. P., \& Finlayson, M. A. J. (1978). Neuropsychological significance of variations in patterns of academic performance: Verbal and visual-spatial abilities. Journal of Abnormal Child Psychology, 6(1), 121-133. doi: $\underline{10.1007 / \mathrm{BF} 00915788}$

Schulte-Körne, G., Deimel, W., Müller, K., Gutenbrunner, C., \& Remschmidt, H. (1996). Familial aggregation of spelling disability. Journal of Child Psychology and Psychiatry and Allied Disciplines, 37(7), 817-822. doi: 10.1111/j.14697610.1996.tb01477.x

Shaywitz, S., Colker, R., Shaywitz, B., \& Simon, J. A. (2012). Comments on proposed DSM-5 criteria for specific learning disorder from a legal and medical/scientific perspective Professor Ruth Colker, JD Distinguished University Professor Heck-Faust Memorial Chair in Constitutional Law. Diunduh dari http://dyslexia.yale.edu/wpcontent/uploads/2017/09/CommentsD SM5ColkerShaywitzSimon.pdf

Shaywitz, S. E., Morris, R., \& Shaywitz, B. A. (2008). The education of dyslexic children from childhood to young adulthood. Annual Review of Psychology, 59, 451-475. doi: 10.1146/annurev.psych.59.103006.0936 $\underline{33}$

Siegel, L. S. (1992). An evaluation of the discrepancy definition of dyslexia. Journal of Learning Disabilities, 25(10), 618-629. doi: $10.1177 / 0022219$ $\underline{49202501001}$

Siegel, L. S, \& Feldman, W. (1983). Nondyslexic children with combined writing and arithmetic difficulties. Clinical Pediatrics, 22, 241-244.

Siegel, L. S. (1989). IQ is irrelevant to the definition of learning disabilities. Journal of Learning Disabilities, 22(8), 469. doi: $10.1177 / 0143034305055975$

Siegel, L. S. (2003). The diagnosis of LD: Introduction to the special issue. Journal of Learning Disabilities, 36(1), 23.

Siegel, L. S., \& Ryan, E. B. (2018). The development of working memory in normally achieving and subtypes of learning disabled children. Child Development, 60(4), 973-980. doi. 10.1111/j.1467-8624.1989.tb03528.x

Stanovich, K. E. (2008). The future of a mistake: Will discrepancy measurement continue to make the learning disabilities field a pseudoscience? Learning Disability Quarterly, 28(2), 103. doi: $\underline{10.2307 / 1593604}$

Stuebing, K. K., Barth, A. E., Molfese, P. J., Weiss, B., \& Fletcher, J. M. (2009). IQ is not strongly related to response to reading instruction: A meta-analytic interpretation. Council for Exceptional Children, 76(1), 31-51.

Stuebing, K. K., Fletcher, J. M., LeDoux, J. M., Lyon, G. R., Shaywitz, S. E., \& Shaywitz, B. A. (2002). Validity of IQdiscrepancy classifications of reading 
disabilities: A meta-analysis. American Educational Research Journal, 39(2), 469518. doi: $10.3102 / 00028312039002469$

Tanaka, H., Black, J. M., Hulme, C., Stanley, L. M., Kesler, S. R., WhitfieldGabrieli, S., ... Hoeft, F. (2011). The brain basis of the phonological deficit in dyslexia is independent of IQ. Psychological Science, 22(11), 1442-1451. doi: $\underline{10.1177 / 0956797611419521}$

Tannock, R. (2014). DSM-5 Changes in diagnostic criteria for Specific Learning Disabilities (SLD). Diunduh dari https://dyslexiaida.org/dsm-5changes-in-diagnostic-criteria-forspecific-learning-disabilities-sld1what-are-the-implications/

Vaughn, S., \& Fuchs, L. S. (2003). Redefining learning disabilities as inadequate response to instruction: The promise and potential problems.
Learning Disabilities Research and Practice, 18(3), 137-146. doi: $\underline{10.1111 / 1540-5826.00070}$

Vellutino, F. R., Scanlon, D. M., \& Lyon, G. R. (2000). Differentiating between difficult-to-remediate and readily more evidence against the IQachievement discrepancy definition of reading disability. Journal of Learning Disabilities, 33(3), 223-238. doi: $\underline{10.1177 / 002221940003300302}$

Wagner, R. F. (1973). Rudolf Berlin: Originator of the term dyslexia. Bulletin of the Orton Society, 23(1), 5763. doi: $\underline{10.1007 / \mathrm{bf02653841}}$

Zumeta, R. O., Zirkel, P. A., \& Danielson, L. (2014). Identifying specific learning disabilities: Legislation, regulation, and court decisions. Topics in Language Disorders, 34(1), 8-24. doi: $\underline{\text { 10.1097/TLD.0000000000000006 }}$ 